\title{
FLÁVIO SUPLICY DE LACERDA: GENEALOGIA DE UM INTEGRANTE DA ELITE PARANAENSE
}

\author{
Névio de Campos
}

\begin{abstract}
RESUMO
Este artigo objetiva discutir alguns aspectos da trajetória de Flávio Suplicy de Lacerda, enfatizando sua genealogia familiar (capital social) e o capital cultural herdado e adquirido como trunfos utilizados para ocupar a reitoria da Universidade do Paraná, e as funções de Secretário do Estado paranaense, e de Ministro da Educação no governo militar de Castelo Branco. A hipótese afirma que o espirito de família e a herança cultural, se constituíram em estratégias utilizadas por Flávio de Lacerda para assumir funções de destaque no cenário cultural e político do Paraná e do Brasil, e foi discutida à luz dos conceitos de trajetória, estratégia, espirito de família e capital cultural herdado e adquirido, a partir de dados biográficos e autobiográficos. Esses dados foram tomados como produção de uma memória ou/e uma representação que buscava sacralizar essa personagem. As descrições biográficas, por sua vez, foram cruzadas com os contextos social e cultural, permitindo pôr em jogo o aparato teórico e o objeto empírico. Esta análise permite afirmar que as estruturas estruturadas se converteram em estruturas estruturantes na trajetória de Flávio de Lacerda, isto é, esse intelectual, ao interiorizar as estruturas estruturadas, incorporou o senso prático como sentido de jogo, como estratégia para ingressar no campo intelectual, assim como para ampliar seus espaços de ação nesse próprio campo. Em síntese, ao tomar os dados como tentativa de sacralização da trajetória de Flávio de Lacerda e convertê-los em produtos do processo dos contextos social e cultural, este artigo contribui ao entendimento da complexa relação entre o indivíduo e a sociedade, isto é, evidencia que os trunfos sociais e culturais funcionam como poderosas estratégias para assumir papeis de liderança nos campos político e cultural.
\end{abstract}

PALAVRAS-CHAVE: trajetória; estratégia; espirito de família; capital cultural herdado; elite paranaense.

\section{INTRODUÇÃO}

Este trabalho objetiva discutir alguns aspectos da trajetória de Flávio Suplicy de Lacerda, particularmente sua genealogia familiar e seu capital cultural herdado e adquirido ${ }^{1}$. As razões que justificam essa pretensão

\footnotetext{
${ }^{1}$ É importante destacar ao leitor que este texto não problematiza a atuação de Flávio de Lacerda no campo intelectual e na esfera política do Paraná (Reitoria da Universidade Federal do Paraná (UFPR)) e do Brasil (Ministério da Educação), mas pretende reconstituir alguns elementos de sua origem social (familiar) e de sua trajetória educativa, objetivando indicar que esses elementos, juntamente com suas tomadas de posições nos campos político e acadêmico, são chaves explicativas da sua ação no campo intelectual. Em razão disso, não discutimos intensamente o problema da autonomia do campo intelectual e sua relação com o campo do poder e outros espaços sociais. No livro "Intelectuais paranaenses e concepções de universidade", de minha autoria, há uma discussão referente ao processo de federalização da Universidade do Paraná, coordenado por Flávio de Lacerda. Há projetos em andamento que produzirão análises específicas da inserção de Flávio de Lacerda no campo intelectual paranaense, enfatizando sua atuação na reitoria da Universidade do Paraná. Também agradeço aos pareceristas anônimos da Revista de Sociologia e Política por seus comentários e sugestões.
}

analítica estão associadas ao lugar que Flávio de Lacerda ocupou no cenário político e intelectual da história paranaense e brasileira. Em rigor, ele ocupou por duas décadas a reitoria da Universidade do Paraná (1949-1964; 1967-1971), assim como funções em secretarias do Estado paranaense e de Ministro da Educação no período de 1964 a 1966.

Em 1948, Flávio de Lacerda assumiu a vice-reitoria da Universidade do Paraná (UP). Em 4 de agosto de 1949 , assumiu a reitoria devido ao falecimento do Reitor João Ribeiro de Macedo Filho. No dia 19 dezembro de 1949, lançou o movimento pela federalização da UP. Em 19 de dezembro de 1950, a UP foi federalizada. Ao consultar os documentos referentes ao processo de federalização da UP, particularmente os relatórios da instituição, onde constam inúmeros discursos, é possível perceber que Flávio de Lacerda exerceu um papel de organização e mobilização da comunidade acadêmica e da classe política para lutarem em defesa da Universidade ${ }^{2}$. Além de cargos na Universidade, também ocupou funções nos órgãos administrativos do Estado do Paraná e da

2 Consultar Campos (2008). 
União. Em 1946, ele assumiu a Secretaria de Viação de Obras Públicas no governo do interventor Brasil Pinheiro Machado ${ }^{3}$. Porém, sua presença em cargos estatais de maior relevância, aconteceu quando assumiu o Ministério da Educação, no governo militar de Marechal Humberto de Alencar Castelo Branco, nomeado em 15 de abril de 1964.

Pretende-se problematizar o espírito de família e capital cultural como estratégias utilizadas por Flávio de Lacerda para assumir funções de destaque no cenário cultural e político do Paraná e do Brasil. Utilizaremos as categorias de "espírito de família" e "capital cultural herdado e adquirido", pois entendemos que a sua genealogia familiar e o acesso aos espaços de educação formal constituem uma parte dos argumentos para explicar as razões da incursão desse intelectual nos principais espaços culturais e políticos do Paraná e do Brasil ${ }^{4}$.

A “existência de uma rede de relações não é um dado natural, nem mesmo um 'dado social', constituído de uma vez por todas e para sempre por um ato social de instituição [...]" (BOURDIEU, 1998a, p. 68). Entretanto, assevera o sociólogo francês, a rede de relações é "“[...] o produto do trabalho de instauração e de manutenção que é necessário para produzir e reproduzir relações duráveis e úteis, aptos a proporcionar lucros materiais ou simbólicos". Ou ainda, “[...] é produto das estratégias de investimento social consciente ou inconscientemente orientadas para a instituição ou a reprodução de relações sociais diretamente utilizáveis [...]" (ibidem). Para Bourdieu, embora exista uma autonomia relativa do campo cultural, há interdependência entre os campos cultural e social, pois “[...] o rendimento escolar da ação escolar depende do capital cultural previamente investido pela família e [...] o rendimento econômico e social do certificado escolar depende do capital social - também herdado que pode ser colocado a seu serviço" (idem, p. 74).

A análise dessas facetas da trajetória de Flávio de Lacerda tem a pretensão de trazer à baila alguns aspectos das ações dessa personalidade. Entretanto, é importante ressaltar que esta narrativa não compreende

3 Brasil Pinheiro Machado exerceu o papel de interventor de 25 de fevereiro de 1946 a 21 de setembro de 1946. Com sua saída do governo, Flávio de Lacerda deixou a Secretaria de Obras Públicas.

4 O recorte nas categorias de espírito de família e capital cultural herdado e adquirido não implica a supressão do caráter explicativo das razões do próprio campo intelectual paranaense para a assunção de Flávio de Lacerda nos principais cargos da UFPR e do MEC. Desse modo, enfatizamos o período que antecede o ingresso dessa personagem na Faculdade de Engenharia do Paraná (1930). a trajetória de Lacerda como um caminho determinado, desde o início de sua vida. Ao contrário, dialoga com Pierre Bourdieu - para quem trajetória é "[...] uma série de posições sucessivamente ocupadas por um mesmo agente [...], em um espaço ele próprio em devir e submetido a transformações incessantes" (BOURDIEU, 2008, p. 81).

Tal definição contribui para relativizar uma tendência forte na história biográfica, que tem a "[...] preocupação de atribuir sentido, de encontrar a razão, de descobrir uma lógica ao mesmo tempo retrospectiva e prospectiva, uma consistência e uma constância, de estabelecer relações inteligíveis, como a do efeito com a causa eficiente, entre estados sucessivos, constituídos como etapas de um desenvolvimento necessário" (idem, p. 75).

Por outro lado, é importante sustentar que essa contribuição de Bourdieu não desconsidera a articulação das diferentes posições da trajetória de um intelectual. Nesse sentido, nossa pretensão analítica tem o cuidado em não tomar a trajetória tal qual entendia a história biográfica que apregoava um curso, um caminho já determinado, seja a partir de uma visão retrospectiva, seja prospectiva.

\section{FLÁVIO SUPLICY DE LACERDA E ESPÍRITO DE FAMÍLIA}

Flávio Suplicy de Lacerda nasceu na Lapa. É originário de uma cidade marcada pelo ambiente cultural e político do Paraná tradicional (Campos Gerais), pois, no século XIX, dessa região saíram diversas autoridades políticas que ocupavam espaços na administração pública. No século XX, os grupos políticos dos Campos Gerais continuam com presença marcante no cenário paranaense, embora no final da primeira metade dos novecentos, novos grupos passam a compor forças na administração estatal, como por exemplo, as forças políticas do Paraná moderno (Norte do Paraná).

A cidade natal de Flávio de Lacerda originou-se de um pequeno povoado fundado às margens da antiga Estrada da Mata (ligava Rio Grande do Sul a São Paulo, desempenhando importante papel no progresso do interior paranaense), que era apenas uma parte do histórico Caminho de Sorocaba, por onde circulavam tropas vindas do Rio Grande do Sul com destino à feira de Sorocaba. A primeira denominação era Pouso de Capão Alto (1731). Em 13 de junho de 1797, o Pouso foi elevado à categoria de Freguesia, quando o Capitão Francisco Teixeira Coelho (português) assumiu a função de comandante. Em 6 de junho de 1806, foi elevada a vila, recebendo o nome de Vila Nova do Príncipe. Em 1870, passou a ser sede de Comarca, assumindo a função de Juiz Antonio Cândido Ferreira de Abreu. Por 
fim, em 7 de março de 1872 foi elevada à categoria de município e cidade, com território desmembrado de Curitiba e passando a chamar-se Lapa.

A região dos Campos Gerais materializou o predomínio dos interesses da oligarquia agrária. Sua organização econômica consubstanciava-se na criação e comércio de gado e na produção agrícola (ervamate). O início do século XVIII marcou a ocupação da região dos Campos Gerais. Inicialmente foi ocupada por famílias originárias de São Paulo, Santos e Paranaguá (primeira cidade do Paraná). No final do século XVIII quase toda a área estava povoada, embora escassamente, pois existiam propriedades muito grandes para comportar a pecuária expansiva. A pecuária passou a dominar a economia regional. Quem possuía recursos investia-os na compra de gado no Rio Grande do Sul, para revender na feira de Sorocaba. Surgia, então, o tropeiro, intermediário entre o criador e o comprador.

Na avaliação de Carlos Vicente Ferreira, "são os tropeiros de 'tiro longo e os de tiro curto' ou 'malas nos tentos', com capital suficiente para sustentar toda a longa operação desde a compra do gado no sul, a recuperação nos Campos Gerais e a revenda em Sorocaba. Os segundos, às vezes, simplesmente reduziam-se a condutores das tropas" (FERREIRA, 1996, p. 41).

A baixa na produção de metais preciosos em Minas Gerais representou a desagregação do sistema comercial dos fazendeiros (tropeiros) dos Campos Gerais. Não obstante, com a expansão da produção de café em São Paulo, no segundo quartel do século XIX, "o tropeirismo ganha novos mercados e conhece o apogeu, em meados do século passado [XIX]" (ibidem). Esse negócio promissor manteve até o final do século XVIII quando foi criada a rodovia Centro-Sul do país (Minas Gerais, Rio de Janeiro e São Paulo), o que implicou a redução da procura de muares. Em termos quantitativos é exemplar a passagem seguinte: "a feira de Sorocaba, que ainda, em 1860 negociava 100 mil animais, não movimentava mais que 5 mil nos anos finais do século passado [XIX]. Com o ciclo dos tropeiros arquivado, a economia ficou estagnada" (ibidem). De acordo com as observações de Rui Wachowicz, "o dono das tropas não era um homem pobre. A formação de uma tropa requeria quantias razoáveis, sendo a maioria de seus proprietários homens abastados e de destaque" (WACHOWICZ, 1977, p. 72).

Os proprietários dos campos do planalto curitibano, desde o segundo quartel do século XVIII, iniciaram a criação de gado, ou seja, os tropeiros transformaram-se em criadores de gado. De "zona de passagem a princípio, os Campos Gerais [segundo planalto paranaense] tornaram-se, também logo depois, zona produtora" (FERREIRA, 1996, p. 43). Foi no planalto curitibano que se iniciou a produção de ervamate, produto que sustentou a economia paranaense por mais de um século, logo se espalhando por cidades dos Campos Gerais, como por exemplo, Lapa. A produção da erva-mate paranaense passou a atender aos mercados argentinos. Na avaliação de Wachowicz, "esse produto de exportação vai se transformar em esteio da economia paranaense, sobretudo no período provincial. Foi uma época de ouro. Houve períodos em que o produto chegou a representar $85 \%$ da economia da província" (WACHOWICZ, 1977, p. 96). A erva-mate produzida nos planaltos paranaenses passava pelo processo industrial no litoral, logo, a oligarquia de Morretes, Paranaguá e Antonina beneficiava-se de maior parte do lucro. A ascensão da oligarquia litorânea representou a relativização do poder da oligarquia campeira.

Até o penúltimo quartel do século XIX, o grupo ligado ao latifúndio dos Campos Gerais controlava a maior parte do poder econômico e do poder de governo no Paraná. Havia o grupo do litoral, atrelado ao comércio da erva-mate, porém com poder muito menor. Esse cenário começou a mudar a partir do último quartel do mesmo século, caracterizado por um processo de desagregação dos negócios agrários, bem como pelo crescimento substancial da industrialização da produção do mate. No plano econômico, houve retrocesso da força da oligarquia agrária e avanço da potência da oligarquia do litoral do Paraná. Na esfera política, as disputas estavam abertas, com expressiva força majoritária dos latifundiários no Congresso Paranaense, o que permitia a manutenção de diretrizes a favor desse grupo. No entanto, a ação de Ildefonso Correia (Barão do Serro Azul), principal liderança do Partido Conservador e representante da oligarquia do litoral (comerciantes de erva-mate) consistiu na representação típica contra os mandos dos políticos dos Campos Gerais.

Em termos tipológicos é possível sustentar que os fazendeiros, também conhecidos por senhores dos Campos Gerais, estavam associados aos latifúndios agropastoris, pecuária bovina e invernagem e comércio de muares provenientes do Rio Grande do Sul. Estavam atrelados também ao trabalho escravo, à regulamentação moral dos mercados de abastecimento, ao incentivo à imigração europeia e ao monopólio da representação política, pois os especialistas (bacharéis, médicos e engenheiros) - filhos dos fazendeiros ocupavam grande parte dos empregos públicos e dos cargos de representação política da Província.

A família de Flávio de Lacerda era proprietária de terras e de escravos. Seu bisavô (Frederico Virmond) 
e seu avô (Jean F. Suplicy) tinham fazendas na Lapa. Na região desse município existia a Colônia Virmond, o que indica o grau de influência de sua família na história da cidade. Lacerda Neto descreve que, na casa de Flávio de Lacerda, "coabitava [...] a negra Carlota [...], exescrava de Frederico Virmond, alforriada por Duca [pai de Flávio] antes da abolição da escravatura e que passou a compartir do mesmo teto ao enviuvar e até falecer octogenária em 1923" (LACERDA NETO, 1988, p. 10).

A visão de mundo da região de origem de Flávio de Lacerda é constituída por essa ambiência cultural e política. Embora, o controle político estivesse associado a esses grupos políticos, as funções intermediárias eram ocupadas por pessoas que detinham determinados capitais - verdadeiros trunfos para ingressar em uma sociedade conformada pela condição aristocrática, embora formalmente inexistisse uma sociedade aristocrática, pois todos eram cidadãos, igualmente reconhecidos pela constituição republicana. A família de Flávio Suplicy de Lacerda era detentora de propriedades rurais, além de ser herdeira de um conjunto de elementos que a distinguia, ou melhor, que a identificava com a condição aristocrática - pois acumulava títulos próprios dos grupos distintos, particularmente os títulos associados ao talento (diplomas, bibliotecas particulares, gosto artístico etc.), bem como ascendência de nobreza europeia e brasileira. Entretanto, a esses trunfos é importante associar a vinculação desses grupos com a classe governante e dominante do Paraná. Em termos bourdieusianos, é fecunda a hipótese de que as famílias detentoras de capital cultural potencializam, ou melhor, fazem valer, de fato, seus trunfos culturais na medida em que se integram às famílias da classe política.

Flávio Suplicy de Lacerda é filho de Alice Maria Virmond Suplicy e Manuel José Corrêa de Lacerda. Ele nasceu no dia 4 de outubro de 1903, antepenúltimo de 14 filhos do casal Alice Maria e Manuel José. Seu pai possuía uma loja de armarinhos, ou seja, exercia oficio na área do comércio. Porém, teve forte envolvimento na resistência da Lapa, ao secretariar a segunda brigada pica-pau e elaborar o termo de capitulação. Portanto, sua posição política estava vinculada ao grupo de Julio de Castilhos e de Floriano Peixoto.

A afeição de Manuel de Lacerda com o comércio tem relação com a experiência de seu pai, que trabalhava no ofício de comerciante de secos e molhados. O avô de Flávio de Lacerda, cujo nome era também Manuel José Corrêa de Lacerda, nasceu em Portugal (Porto), migrando para o Rio de Janeiro por volta de 1832, quando trabalhava como caixeiro viajante, fornecendo artigos para a região das províncias do sul do Brasil. Em Paranaguá, conheceu Leocádia Cassiana Pereira de Rezende, com quem se casou em 1843. Após o casamento, partiram para a Vila Nova do Príncipe. Consequentemente, a família paterna de Flávio Suplicy de Lacerda chegou à Lapa na década de 1840 . Comerciante na Lapa, Manuel de Lacerda também era proprietário de escravos. Tal observação é informada por Lacerda Neto ao indicar que Manuel de Lacerda possuía "[...] treze escravos" (idem, p. 8).

Após essa discussão geral a respeito da origem familiar de Flávio de Lacerda, apresentamos quadros sintéticos que evidenciam uma genealogia mais completa desse intelectual paranaense.

QUADRO 1 - GENEALOGIA DE FLÁVIO S. DE LACERDA (1ª-4a GERAÇÕES)

\begin{tabular}{|c|c|c|}
\hline Geração & Nome & Descrição \\
\hline $1^{a}$ & Flávio Suplicy de Lacerda & Filho \\
\hline $2^{a}$ & $\begin{array}{l}\text { Alice Maria Suplicy de Lacerda } \\
\text { Manuel José Corrêa de Lacerda }\end{array}$ & Pais de Flávio S. de Lacerda \\
\hline $3^{a}$ & $\begin{array}{l}\text { Leocádia C. Pereira de Rezende } \\
\text { Manuel José Corrêa de Lacerda }\end{array}$ & Avós paternos de Flávio Suplicy \\
\hline $3^{a}$ & $\begin{array}{l}\text { Maria Luiza E. Virmond } \\
\text { Jean François J. E. S. Victor Suplicy }\end{array}$ & Avós maternos de Flávio Suplicy \\
\hline $4^{a}$ & $\begin{array}{l}\text { Rita Joaquina Guimarães (mãe de Leocádia) } \\
\text { Joaquim P. de Rezende (pai de Leocádia) }\end{array}$ & Bisavós de Flávio Suplicy \\
\hline $4^{a}$ & $\begin{array}{l}\text { Vitória J. de Santa Cruz (mãe do avô Manuel) } \\
\text { Joaquim J. C. de Lacerda (pai do avô Manuel) }\end{array}$ & Bisavós de Flávio Suplicy \\
\hline $4^{a}$ & $\begin{array}{l}\text { Maria I. Q. de Andrade (mãe de M. Luiza) } \\
\text { Frederico G. Virmond (pai de M. Luiza) }\end{array}$ & Bisavós de Flávio de Lacerda \\
\hline $4^{a}$ & $\begin{array}{l}\text { Ursula Bonin (mãe de Jean François) } \\
\text { Germain L. de. M. Supplicy (pai de Jean F.) }\end{array}$ & Bisavós de Flávio de Lacerda \\
\hline
\end{tabular}

FONTE: O autor, a partir de Lacerda Neto (1988). 
O Quadro 1 indica os nomes dos pais, avós e bisavós de Flávio de Lacerda. O antepassado direto de Flávio de Lacerda mais antigo que localizamos é Manuel José Corrêa de Lacerda, nascido em Vila de Viana (Portugal), aproximadamente em 1765. Já no Porto, em torno de 1790 teve seu filho chamado Joaquim José Corrêa de Lacerda. Em Portugal nasceu Manuel José Corrêa de Lacerda, filho de Joaquim José, homônimo de seu avô. Manuel J. C. de Lacerda veio para o Brasil por volta de $1832^{5}$. No entanto, na biografia escrita por Arthur Virmond de Lacerda Neto, há uma reconstituição da origem do nome "Lacerda" que remonta ao século XIII ${ }^{6}$. "As origens por via paterna remontam seu primórdio ao ano de 1256 , precisamente a 24 de janeiro, natalício do Infante de Castela, Dom Fernando, filho de Afonso X, O Sábio, que nascendo com madeira de pelos torácicos, ou ao ombro, recebeu o cognome 'de la cerda', significando 'o pelo' e originando por alterações ulteriores a grafia que se fixou como definitiva, a saber 'Lacerda"' (idem, p. 1$)^{7}$.

A migração para Portugal é descrita por Lacerda Neto nos seguintes termos: "[...] Dom Carlos de la Cerda, Conde de Angoulême em França e pai de uma filha natural que desposando a Diogo Nunes de Serpa forma a sua vez o casal genitor do fidalgo castelhano Martim Gonçalves de la Cerda, fixado em Portugal no início da segunda dinastia portuguesa, ainda no reinado de Dom João I (1358-1433)” (idem, p. 1).

De acordo com Lacerda Neto, do casamento de Martim Gonçalves de la Cerda e Violante Pereira (filha do Prior do Crato, Dom Alvaro Gonçalves Pereira) “[...] originou-se o sobrenome em sua versão definitiva, pela aglutinação preposicional sob a forma composta Pereira de Lacerda, tronco da família em Portugal" (ibidem $)^{8}$. De acordo com Ricardo de Oliveira, "os mais conhecidos Lacerda foram o Coronel e Senador Joaquim Rezende Correa de Lacerda [tio de Flávio de Lacerda], um dos defensores da Lapa em 1894, e Flávio Suplicy de Lacerda [...]. Título Rodrigues de França"9 (R. C. OLIVEIRA, 2001, p. 282).

A família Suplicy também tem história recente no Brasil. Na biografia de Flávio de Lacerda, escrita por Arthur Virmond de Lacerda Neto, observa-se que a genealogia da família Suplicy vincula-se a linhagem nobre da França do final do século XVII: "descendia de Pierre Jean Supplicy, 'capitoul' da cidade (espécie de governador local) em 1696, e através dele, em gerações anteriores, do nobre Jean François de Supplicy Marsas, advogado à câmara alta local [...]. O filho deste, Germain Louis de Magdelaine Supplicy, nascera em 1768, tendo por padrinho batismal ao Barão de Marsas, certamente seu tio" (LACERDA NETO, 1988, p. 4-5). Na sequência, relata Lacerda Neto que Germain de Supplicy teve dois filhos (Louis Jean Joseph Supplicy e Jean François Jacques Etienne Servin Victor Supplicy. Em 1834, esses dois irmãos migraram para o Brasil, passando a residir no Rio de Janeiro e a trabalhar como ourives. Em terras brasileiras, Jean François casou-se com Maria Luiza Edeltrudes Virmond (avós maternos de Flávio de Lacerda).

No Quadro 2, a seguir, há uma síntese da genealogia da família Virmond, tronco importante da ascendência de Flávio de Lacerda.

\footnotetext{
5 Em rigor, o nome Lacerda estava presente no processo de colonização portuguesa, instalando-se na Bahia e no Rio de Janeiro.

6 Dom Fernando nasceu em 1255 e faleceu em 1275, na Cidade Real. Príncipe herdeiro. Casou-se em 1269, em Burgos, com Branca de França, filha do Rei Luis IX da França. Informações obtidas em ABCGenealogia (2013).

7 Do casamento de Dom Fernando e Branca (princesa da França) nasceram dois filhos, sendo Dom Afonso de la Cerda o primogênito e herdeiro do reino de Castela. Um dos filhos de Dom Afonso, chamado Afonso da Espanha, foi pai de Dom

Carlos de la Cerda (Conde de Angoulême), avô de Martim Gonçalves de la Cerda que migrou para Portugal.

8 A origem do nome Lacerda remonta ao contexto da história da Espanha (século XIII), cuja migração para Portugal aconteceu no final do século XIV. Porém, a linhagem direta de Flávio de Lacerda tem registro em "Porto-Portugal/meados do século XIX” (R. C. OLIVEIRA, 2001, p. 282).

9 Título Rodrigues de França “[...] é a família do Capitão-Mor (1707-1715) de Paranaguá, João Rodrigues de França e sua longa descendência. Ele foi morador de Santos e possuía minas de ouro em Arassatuba e fazendas de criação nos Campos Gerais. É o tronco da elite do litoral" (idem, p. 272).
} 
QUADRO 2-GENEALOGIADA FAMÍLIA VIRMOND

\begin{tabular}{|lcc|}
\hline Geração & Nome & Descrição \\
\hline $1^{\mathrm{a}}$ & Flávio S. de Lacerda & Filho \\
\hline $2^{\mathrm{a}}$ & Alice Maria S. de Lacerda & Mãe de Flávio de Lacerda \\
\hline $3^{\mathrm{a}}$ & Maria Luiza Edeltrudes Virmond & Avó de Flávio de Lacerda \\
\hline $4^{\mathrm{a}}$ & Frederico Guilherme Virmond & Maria Isabel de Andrade \\
& Johann Henrich Virmond & Bisavô de Flávio de Lacerda \\
\hline $6^{\mathrm{a}}$ & Isaac Virmond & Bisavó de Flávio de Lacerda \\
\hline $7^{\mathrm{a}}$ & Avô de Frederico Virmond \\
\hline
\end{tabular}

FONTE: O autor, a partir de Lacerda Neto (1988).

O nome Virmond, da linhagem de Maria Luiza, veio para o Brasil com Frederico Virmond (bisavô materno de Flávio de Lacerda). Frederico Virmond é nascido em Colônia (Alemanha) no ano de 1791. Em razão de entrar em combate com as forças napoleônicas teve de emigrar para o Brasil, chegando ao Rio de Janeiro em 1818. No Rio de Janeiro, sua ocupação estava associada à casa de importação. De acordo com Lacerda Neto, “[...] tornou-se maçom assíduo embora tivesse sido co-fundador da primeira paróquia protestante no país, terminando a vida em salutar ateísmo" (idem, p. 5). Em 1833, mudou-se para a cidade da Lapa, exercendo atividades de engenharia, medicina e pintor miniaturista. A linhagem da mãe de Flávio de Lacerda estabeleceu-se na cidade da Lapa na década de 1830. De acordo com Francisco Negrão, os descendentes de Frederico G. Virmond "[...] se casaram entre as famílias principais da Lapa" (Negrão apud R. C. OLIVEIRA, 2001, p. 291).

Por outro lado, a avó Leocádia Cassiana Pereira de Rezende era sobrinha de Manuel Antônio Guimarães $^{12}$, conhecido como Visconde de Nácar ${ }^{13}$

10 Neta materna do tesoureiro-mor de Dom João VI, Manuel Ferreira de Andrade.

11 Não localizamos o nome do pai de Frederico Virmond. Em razão disso, no quadro há um salto da $4^{\mathrm{a}}$ à $6^{\mathrm{a}}$ geração.

12 De acordo com Negrão (apud R. C. OLIVEIRA, 2001, p. 273), a família Guimarães “[...] tem origem a partir do português Manuel Gonçalves Guimarães, coronel, grande empreendedor no final do século XVIII. Grande proprietário de terras, assinou o auto de ereção da Vila de Castro em 1789. Tropeiro, contratador dos impostos do Porto de Cima e do Rio Negro, minerador no Tibagi, motivo pelo qual foi preso pela Coroa por não ter pago quinto de imposto, enviado preso para Portugal e retorna ao Paraná [...]. Casou-se com Maria Magdalena de Lima, filha do Capitão-Mor de Paranaguá, em 1776 [...]. Manuel Gonçalves Guimarães teve vários filhos. A sua filha Anna Ubaldina de Guimarães e Silva casou-se com João da Silva Machado, Barão de Antonina “. Manuel G. Guimarães e do Comendador Joaquim Américo Guimarães ${ }^{14}$. Além disso, sua família já estava há muito tempo em terras brasileiras. É possível afirmar que essa linhagem da ascendência paterna de Flávio de Lacerda estava diretamente associada à nobreza brasileira, pois sua avó era sobrinha de um Visconde e Comendador, portanto, de homens que possuíam títulos nobiliárquicos.

Na avaliação de Ricardo Costa de Oliveira, "desde o século XVIII a parentela de Manuel Antonio Guimarães, o Visconde de Nácar, importante ervateiro e proprietário escravista, sempre reproduzem as relações entre grandes empreendimentos econômicos

era avô do Visconde de Nácar. "Título Cardoso de Lima. Pelo Visconde de Nácar, título Rodrigues de França” (ibidem). Ainda segundo Negrão, o Título Cardoso de Lima está associado ao Sargento-Mor Domingos Cardoso de Lima, natural do Porto, o qual chegou ao Paraná no século XVIII. "Possuidor de minas de ouro em Morretes e Anhaia. Possuía grandes cabedais. [...] Vereador em Paranaguá. Foi indicado em 1765 para ser CapitãoMor de Paranaguá [...]" (idem, p. 281-282).

13 Segundo Knebel , "Manuel Antônio Guimarães nasceu em Paranaguá a 15 de fevereiro de 1813, filho de Maria da Luz e do Capitão Joaquim Antônio Guimarães. Entre 1850 e 1889 foi líder do Partido Conservador e em 1851 deputado na Assembléia Provincial de São Paulo e, após a emancipação, na Assembléia Provincial do Paraná. Além disso, foi deputado geral em Paranaguá (1886 e 1889), presidente da Câmara Municipal, delegado de Polícia e comandante superior da Guarda Nacional. Em 21 de julho de 1876 foi agraciado com o título de Barão e em 1880 com o de Visconde, isso tudo após já ter recebido o Hábito de Cristo e Ter sido comendador e dignatário da Ordem da Rosa e cavaleiro imperial da Ordem do Cruzeiro. Morreu em 16 de agosto de 1893 em Paranaguá” (KNEBEL, s. d., s. p.).

14 “Comendador Joaquim Américo Guimarães. Irmão, por parte de pai, de Manuel Antonio Guimarães, o futuro Visconde de Nácar. Negociante de grosso trato. Matriculado na Junta do Comércio do Rio de Janeiro. Consignatário de várias embarcações. Proprietário de vários imóveis urbanos" (R. C. OLIVEIRA, 2001, p. 56). 
e posições no aparelho de Estado e na magistratura" (R. C. OLIVEIRA, 2007, p. 161).

Em rigor, conforme Ricardo de Oliveira, "poucos grupos familiares detinham o grande negócio comercial no litoral. A família Correia, Guimarães, Pereira e Gonçalves Cordeiro, todos com parentesco entre eles" (R. C. OLIVEIRA, 2001, p. 55). É interessante a descrição feita por Oliveira a respeito de Manuel A. Guimarães: "Negociante de grosso trato. Proprietário de diversos imóveis urbanos e sobrados em Paranaguá. Dono de uma chácara na Ilha da Cotinga com bons prédios. Possuía fazendas agrícolas com engenhos de arros e mandioca. Senhor de mais de 50 escravos. [...] A sua casa comercial fundada em 1830, atravessaria o século, sendo exportadora de erva-mate, arroz e outros produtos. Seria o maior comerciante de Paranaguá até quase o fim do século [...]" (idem, p. 56).

Além da linhagem Guimarães, outro tronco familiar de Cassiana Leocádia é Rezende. A seguir, no Quadro 3 , apresentamos um quadro genealógico dessa ascendência familiar.

QUADRO 3-GENEALOGIADAFAMÍLIA REZENDE

\begin{tabular}{|c|c|c|}
\hline Geração & Nome & Descrição \\
\hline $1^{a}$ & Flávio S. de Lacerda & Filho \\
\hline $2^{a}$ & Manuel J. Corrêa de Lacerda & Pai de Flávio de Lacerda \\
\hline $3^{a}$ & Manuel J. C. de Lacerda & Avó de Flávio de Lacerda \\
\hline $4^{a}$ & $\begin{array}{l}\text { Joaquim Pereira de Rezende } \\
\text { Rita Joaquina Guimarães }{ }^{15}\end{array}$ & $\begin{array}{l}\text { Pai de Leocádia } \\
\text { Mãe de Leocádia }\end{array}$ \\
\hline $5^{a}$ & $\begin{array}{c}\text { João Mota Pereira (tenente) } \\
\text { Ana F. Torres }\end{array}$ & $\begin{array}{l}\text { Pai de Joaquim P. de Rezende } \\
\text { Mãe de Joaquim P. de Rezende }\end{array}$ \\
\hline $6^{a}$ & $\begin{array}{l}\text { Domingos P. da Silva (tenente) }{ }^{16} \\
\text { Casemira Rodrigues de França }\end{array}$ & $\begin{array}{l}\text { Pai de João M. Pereira } \\
\text { Mãe de João M. Pereira }\end{array}$ \\
\hline $7^{\mathrm{a}}$ & $\begin{array}{c}\text { José da Costa Rezende (capitão) } \\
\text { Maria do Ó }\end{array}$ & $\begin{array}{l}\text { Pai de Casemia Rodrigues } \\
\text { Mãe de Casemira Rodrigues }\end{array}$ \\
\hline $8^{\mathrm{a}}$ & $\begin{array}{l}\text { André Gonçalves Pinheiro }{ }^{17} \\
\text { Maria de Ascenção Rodrigues }\end{array}$ & $\begin{array}{l}\text { Pai de Maria do Ó } \\
\text { Mãe de Maria do Ó }\end{array}$ \\
\hline $9^{a}$ & $\begin{array}{c}\text { João Rodrigues de França18 } \\
\text { Francisca Pinheiro }\end{array}$ & $\begin{array}{l}\text { Pai de Maria de Ascenção } \\
\text { Mãe de Maria de Ascenção }\end{array}$ \\
\hline $10^{\mathrm{a}}$ & $\begin{array}{l}\text { José Pinheiro } 19 \\
\text { Maria Pinto }\end{array}$ & $\begin{array}{l}\text { Pai de Francisca Pinheiro } \\
\text { Mãe de Francisca Pinheiro }\end{array}$ \\
\hline $11^{a}$ & $\begin{array}{l}\text { Sebastião Machado } \\
\text { Francisca Pinheiro }\end{array}$ & $\begin{array}{l}\text { Pai de José Pinheiro } \\
\text { Mãe de José Pinheiro }\end{array}$ \\
\hline
\end{tabular}

FONTE: O autor, a partir de Lacerda Neto (1988).

Das famílias Guimarães e Rezende, Flávio de Lacerda herdou significativo capital social. Essas linhagens estavam associadas ao grupo político das terras do Paraná. Em relação a esse aspecto observa Ricardo de Oliveira "Basta observar a sucessão de descendentes a partir do Capitão-Povoador de Curitiba,

\footnotetext{
15 Irmã de Visconde de Nácar.

16 Filho dos fundadores da Lapa (Josepha Gonçalves da Silva e João Pereira Braga).

17 Sucessor de João R. de França na função de Capitão-Mor da Capitania de Paranaguá entre 1717 e 1732.
}

Matheus Martins Leme, que com o seu vizinho de sesmaria, Balthazar Carrasco dos Reis, formam os principais povoadores com sesmarias pioneiras na região de Curitiba. Se acrescentarmos os descendentes de João Rodrigues Seixas, primeiro escrivão da Vila

\footnotetext{
18 Filho de Marselha Jacques Frestier, o qual arrematou: “[...] uma data das minas de Itaimbé e, 1679. [João Rodrigues] desempenhou a função de capitão-mor da capitania de Paranaguá, autoridade local suprema de 1701 até sua morte em 1715" (LACERDA NETO, 1988, p. 3).

19 Ele radicou-se em Santos, onde exerceu a função de Tesoureiro dos Reais Quintos de Ouro, falecendo em 1712.
} 
de Curitiba, mais os descendentes de João Rodrigues de França, Capitão-Mor de Paranaguá de 1707 até 1715, mais os do Capitão-Mor Gabriel de Lara e os do Provedor Manuel de Lemos Conde, com estes seis grupos familiares teremos o tronco dos povoadores e fundadores da classe dominante do Paraná. Todos bastante aparentados entre si (idem, p. 40; sem grifos no original).

Ricardo Oliveira, ao discutir a construção da classe dominante histórica do Paraná, é mais preciso ao afirmar que "a morada do poder foi formada pelos grupos de Manuel de Lemos Conde, Gabriel de Lara, Mateus Leme, Baltazar Carrasco dos Reis, João Rodrigues Seixas, João Rodrigues França e Domingos Cardoso de Lima". Ou ainda, “[...] o núcleo duro da classe dominante paranaense é formado com os títulos Carrasco dos Reis, Rodrigues Seixas, Rodrigues França e Cardoso de Lima" (idem, p. 277; sem grifo original).

Para Bourdieu, "capital social é o conjunto de recursos atuais ou potenciais que estão ligados à posse de uma rede durável de relações mais ou menos institucionalizadas de interconhecimento e de interreconhecimento ou, em outros termos, à vinculação a um grupo, como conjunto de agentes que não somente são dotados de propriedades comuns (passíveis de serem percebidas pelo observador, pelos outros ou por eles mesmos), mas também são unidos por ligações permanentes e úteis (BOURDIEU, 1998a, p. 67).
A linhagem de Flávio (Suplicy, Magalhães, Rezende e Virmond) evidencia que sua trajetória é marcada pela ascendência nobre, portanto, detentora de títulos e de reconhecimento entre os grupos dominantes e governantes do Paraná. Além disso, acumularam riquezas nos Campos Gerais, pois, de acordo com Lacerda Neto, "[...] tanto ele [Frederico Virmond] como seu genro [Jean] Suplicy puderam às famílias que encabeçavam propiciar decidido conforto, tendo aquele se dedicado inicialmente ao comércio e este à joalheria [...] para na Lapa tornarem-se fazendeiros [...]" (LACERDA NETO, 1988 , p. 8). Outra estratégia de laço familiar aconteceu com o casamento de Marília Suplicy de Lacerda, irmã de Flávio de Lacerda. Sua irmã casouse com David Antonio da Silva Carneiro - herdeiro de uma das indústrias mais importantes do mate do Paraná. Além disso, o casamento do próprio Flávio de Lacerda expressa um verdadeiro trunfo no processo de reprodução social. Embora não façamos uma construção da ascendência da família da esposa de Flávio de Lacerda, é possível observar que ela remonta ao Rei Afonso Henriques, no século XI, passando pelos reis Afonso II (séc. XII) e Afondo III (séc. XIII), portanto tem origem na nobreza portuguesa.

No Quadro 4, a seguir, sintetizamos alguns dados da família de casamento de Flávio de Lacerda.

QUADRO 4 - FAMÍLIA DE CASAMENTO DE FLÁVIO DE LACERDA

\begin{tabular}{|l|c|c|}
\hline Geração & Nome & Descrição \\
\hline $1^{\mathrm{a}}$ & $\begin{array}{r}\text { Flávio Suplicy de Lacerda Filho } \\
\text { Maria Augusta de Lacerda Pessoa }\end{array}$ & $\begin{array}{c}\text { Filho de Flávio e Dalila } \\
\text { Filha de Flávio e Dalila }\end{array}$ \\
\hline $2^{\mathrm{a}}$ & $\begin{array}{r}\text { Flávio Suplicy de Lacerda } \\
\text { Dalila de Castro Lacerda }\end{array}$ \\
\hline $3^{\mathrm{a}}$ & Vicente de Castro 20 & Pai de Dalila \\
& Maria Augusta da Rocha & Mãe de Dalila \\
\hline
\end{tabular}

FONTE: O autor, a partir de Lacerda Neto (1988).

20 Major Vicente Ferreira de Castro foi o segundo dos filhos de Vicente Ferreira de Castro Alferes e de sua esposa e prima Maria da Conceição de Castro. Em segundas núpcias foi casado com sua prima Maria Augusta da Silva Castro, filha do coronel, Agostinho Vicente de Castro e de Francisca Gonçalves Ribas. Vicente Ferreira de Castro, desde jovem, ingressou na política, abraçando o programa republicano tendo sido o primeiro republicano histórico de Palmeira. Exerceu no Governo Provisório o cargo de Vice-Presidente da Câmara Municipal. Na revolução de 1893-1994, assumiu o comando do Batalhão "Jesuíno Marcondes" e com ele marchou para o Rio Grande do Sul com a Brigada do General Thimotheo Paim, e posteriormente passou a fazer parte da Brigada do General Aparício Saraiva. Depois do falecimento do General Gumercindo
Saraiva, continuou com o General Aparício até emigrarem para a Argentina pela picada da Colônia do Alto Uruguai. Em 1896, passou a residir em Ponta Grossa, tendo alia aos poucos conquistado a chefia política. Até 1922, dirigiu a política de Ponta Grossa. Exerceu o Cargo de Primeiro Suplente de Juiz Federal do Paraná, em 1921 (FILHO, 2004). O pai de Flávio de Lacerda lutou ao lado dos Pica-paus (republicanos); já Vicente de Castro (futuro sogro de Flávio) lutou ao lado dos Maragatos (federalistas). Em 1930, Vicente de Castro lutou ao lado do movimento organizado por Getúlio Vargas. O Exército paranaense aderiu ao movimento de Vargas com a deposição do Presidente do Paraná, Afonso Camargo, e com a tomada do poder pelo General Mario Alves Monteiro Tourinho. De acordo com Lacerda Neto, “[...] ao Movimento de 1930 [Flávio de 
As observações a respeito da ascendência da família de Flávio de Lacerda evidenciam como essa categoria é uma estratégia de reprodução social. A possibilidade de buscar uma genealogia nobre das famílias (Suplicy, Virmond, Rezende e Magalhães) funciona como um trunfo de luta social por reconhecimento (prestígio e distinção), conhecimento, poder e riqueza. Na avaliação de Bourdieu, a família como "[...] categoria mental [...] é a base de milhares de representações e de ações (casamentos, por exemplo) que contribuem para reproduzir a categoria social objetiva" (BOURDIEU, 2008, p. 128). Em outras reflexões, Bourdieu afirma que os casamentos devem ser compreendidos como estratégia social dos grupos. Para ele, “[...] não se pode dissociar as estratégias matrimoniais do conjunto das estratégias - penso, por exemplo, nas estratégias de fecundidade, nas estratégias educativas como estratégias de investimento cultural ou nas estratégias econômicas, investimento, poupança, etc. -, através das quais a família visa se reproduzir biologicamente e sobretudo socialmente, isto é, reproduzir as propriedades que lhe permitem conservar sua posição, sua situação no universo social considerado" (BOURDIEU, 2004, p. 87).

Os quadros organizados têm por objetivo evidenciar que "as estratégias matrimoniais em geral são a resultante de relações de força no interior do grupo doméstico, e essas relações só podem ser entendidas recorrendo-se à história desse grupo, e em particular à história dos casamentos anteriores" (idem, p. 88). As observações de Bourdieu, decorrentes de suas pesquisas, são fecundas para interpretar as estratégias matrimoniais dos ascendentes de Flávio de Lacerda. Segundo Bourdieu, “o casamento não é essa operação pontual e abstrata, baseada unicamente na aplicação de regras de filiação e de aliança, que a tradição estruturalista descreve, mas um ato que integra o conjunto de necessidades inerentes a uma posição na estrutura social, isto é, num estado do jogo dos "negociadores". As relações que se estabelecem entre as famílias por ocasião dos casamentos são tão difíceis e tão importantes quanto as negociações de nossos diplomatas mais refinados [...]" (idem, p. 88).

À luz de Bourdieu é possível indicar que as uniões das famílias de Flávio de Lacerda expressam a "[...] lógica específica das estratégias que os grupos, e

Lacerda] aderiu [...], aquiescendo a conselho do sogro Major Vicente de Castro e integrando-a no posto de Primeiro-Tenente da companhia de equipagem de pontes (capitaneado pelo cunhado Carneiro), incumbida do reparo dos equipamentos (meio-pontões) provenientes de Palmas para se estabelecer passagem sobre o rio Ribeira do Iguape" (LACERDA NETO, 1988, p. 24). particularmente as famílias, empregam para se produzir e se reproduzir [...]" (idem, p. 94). Em outros termos, "[...] para criar e perpetuar sua unidade, logo, sua existência enquanto grupos, o que é quase sempre, e em todas as sociedades, a condição da perpetuação de sua posição no espaço social" (ibidem). Ou em termos sintéticos, “[...] os grupos - familiares ou outros - são coisas que se fazem, à custa de um trabalho permanente de manutenção, do qual os casamentos constituem um momento" (idem, p. 95). Em rigor, “[...] a família tem um papel determinante na manutenção da ordem social, na reprodução, não apenas biológica, mas social, isto é, na reprodução da estrutura do espaço social e das relações sociais" (BOURDIEU, 2008, p. 131). Para o sociólogo francês, "ela é um dos lugares por excelência de acumulação de capital sob seus diferentes tipos e de sua transmissão entre as gerações: ela resguarda sua unidade pela transmissão e para a transmissão, para poder transmitir e porque ela pode transmitir" (idem, p. 131).

As afirmações de Bourdieu são fecundas para problematizar três posições ocupadas por Flávio de Lacerda. A primeira observação diz respeito à sua função na indústria de erva mate de seu cunhado Hildebrando Cesar de Souza Araújo. Em 1929, por convite de Hildebrando, casado com Leopoldina Vicente de Castro (irmã de Dalila de Castro), Flávio de Lacerda assumiu a coordenação dos meios e aparelhos da produção do mate. Em seguida saiu dessa ocupação, pois seu cunhado vendeu sua indústria a Leão Junior. Segundo Bourdieu, "nas corporações [...] a família tem um papel considerável, não apenas na transmissão, mas também na gestão do patrimônio econômico, especialmente através das ligações de negócios que são também, com freqüência, ligações familiares" (idem, p. 133).

A segunda posição foi o ingresso de Flávio de Lacerda à Faculdade de Engenharia do Paraná para exercer a função de docente na cadeira de "resistência dos materiais". Entre 20 de abril de 1930 e janeiro de 1932 foi professor contratado por regime de trabalho temporário. Assumiu novo contrato temporário entre abril de 1932 e janeiro de $1933^{21}$. De acordo com Lacerda Neto, Flávio de Lacerda “deveu as indicações ao cunhado David Carneiro que o apresentou ao Diretor da Faculdade, Professor Affonso Augusto Teixeira de Freitas" (LACERDA NETO, 1988, p. 23; sem grifos no original). A terceira posição refere-se à entrada na Companhia Agrícola e Florestal Monte Alegre para exercer a função de fiscal, "cuja nomeação

\footnotetext{
21 Em junho de 1933 foi aprovado em concurso e tornou-se professor definitivo da Faculdade de Engenharia do Paraná.
} 
recebeu por instância do mesmo cunhado [David Carneiro] junto ao Secretário do Interior, Justiça e Obras Públicas [...], Dr. João David Pernetta [...]" (idem, p. 23). Para Bourdieu, "uma das particularidades dos dominantes é a de possuírem famílias extensas (os grandes têm famílias grandes) e fortemente integradas, já que unidas não apenas pela afinidade dos habitus, mas também pela solidariedade dos interesses, isto é, tanto pelo capital quanto para o capital, o capital econômico, evidentemente, mas também o capital simbólico (o nome) e sobretudo, talvez, o capital social (que sabemos ser a condição e o efeito de uma gestão bem-sucedida do capital coletivo dos membros da unidade doméstica) (BOURDIEU, 2008, p. 132-133).

As relações familiares, isto é, as relações sociais decorrentes das estratégias matrimoniais, são aspectos condicionantes para compreender a trajetória de Flávio de Lacerda. Nesse aspecto, as asserções deste artigo aproximam-se das observações de Sérgio Miceli: "Se na Primeira República o recrutamento dos intelectuais se realizava em função da rede de relações sociais que eles estavam em condições de mobilizar e as diversas tarefas de que se incumbiam estavam quase por completo a reboque das demandas privadas ou das instituições e organização da classe dominante, a cooptação das novas categorias de intelectuais continua dependente do capital de relações sociais mas passa cada vez mais a sofrer a mediação de trunfos escolares e culturais, cujo peso é tanto quanto mais se acentua a concorrência no interior do campo intelectual" (MICELI, 2001b, p. 79).

A investigação de Miceli, cujo recorte analítico problematiza "as relações entre os intelectuais e a classe dirigente no Brasil [...] entre 1920 e 1945" (idem, p. 76), contempla um período do contexto histórico de inserção de Flávio Suplicy de Lacerda nos espaços culturais e políticos do Paraná, embora ele tenha assumido a reitoria da Universidade do Paraná em 1949 e o Ministério da Educação em 1964. Em nossa avaliação, nas décadas de 1930 e 1940, Flávio de Lacerda catalisou as principais forças que o conduziram à direção da UP e do Ministério da Educação.

É importante destacar que, no século XX, passou a existir uma forte articulação entre capital social e capital cultural. Para Bourdieu, "nas sociedades diferenciadas, coloca-se de maneira muito particular a questão absolutamente fundamental em toda a sociedade que é a ordem das sucessões, [...] da perpetuação da linhagem e de sua herança" (BOURDIEU, 2004, p. 231). O sociólogo francês destaca o papel familiar nesse processo sucessório, portanto, o espírito de família tem uma função de produção e reprodução social significativo, embora seja marcado por contradições da própria herança (idem, p. 231-237). Além disso, "em segundo lugar, a transmissão da herança depende dos veredictos das instituições de ensino que funcionam como um princípio da realidade brutal e potente" (idem, p. 231). Nesse sentido, é importante discutir o processo de formação cultural de Flávio de Lacerda, pois além de herdeiro de boas relações sociais, acumulava capital cultural, portanto, sua trajetória pode ser compreendida a partir do espírito de família e do capital cultural.

\section{DA BIBLIOTECA FAMILIAR À ESCOLA DE ENGENHARIA DE SÃO PAULO: TRUNFOS CULTURAIS DE UM HERDEIRO DA ARISTOCRACIA PARANAENSE}

No item anterior, a pretensão foi discutir a rede de relação de Flávio de Lacerda, enfatizando sua linhagem familiar. Pela exposição ficou evidenciado que sua ascendência familiar tinha forte vinculação com a camada social dominante do Paraná. Neste momento, a intenção é analisar o processo de acúmulo de capital cultural na trajetória de Flávio de Lacerda. Em rigor, que condição cultural herdou esse intelectual paranaense? E como converteu esse capital herdado em capital cultural adquirido?

Seus ascendentes eram proprietários de títulos acadêmicos. De acordo com Lacerda Neto, Frederico Virmond (bisavô de Flávio) era "filho e neto de médicos, seu pai formara-se na Universidade de Heidelberg por volta de 1776, seu avô Johan Heinrich estudava medicina na de Estrasburgo em 1748, e ele próprio fora aluno fundador da de Berlim em 1809". Por outro lado, a origem do avô materno (Jean François Supplicy) de Flávio de Lacerda estava associada à área do Direito (LACERDA NETO, 1988, p. 6).

Em relação a Frederico Virmond, Lacerda Neto observa que: "Certamente a maior do sul do país então, sua biblioteca reunia cerca de sete centenas de volumes em alemão, francês e português, sobre filosofia, ciência e literatura. Entre outros bens, integravam seu patrimônio dois pianos de mesa ingleses e uma coleção de coleópteros somando oito mil exemplares, extraviada na exposição de Filadélfia em 1875, para a qual fora remetida (idem, p. 5).

Sem dúvida, há grande imaginação, por parte do biógrafo, para afirmar que a biblioteca de Frederico Virmond tratava-se da maior biblioteca do Sul do Brasil. Talvez fosse, porém, do texto biografado não é possível retirar elementos de evidência. Entretanto, o aspecto importante para este artigo é ressaltar que na trajetória de Frederico Virmond o capital cultural era uma 
estratégia herdada de sua linhagem familiar. Em rigor, a estratégia " [...] é produto do senso prático como sentido do jogo, de um jogo social particular, historicamente definido, que se adquire desde a infância, participando das atividades sociais [...] e outros lugares com certeza, dos jogos infantis" (BOURDIEU, 2004, p. 81).

A outra linhagem (Suplicy) da ascendência materna de Flávio de Lacerda também era portadora de capital cultural. Ademais, conforme Lacerda Neto, Manuel de Lacerda tinha máquina de costura e piano "[...] aparelhos raros à época, sobremodo no interior [...]" (LACERDA NETO, 1988, p. 8). A origem familiar de Flávio de Lacerda acumulava capital cultural nas três formas descritas por Bourdieu. Frederico Virmond era detentor das formas objetiva e institucionalizada que, por sua vez, supõem a existência do estado internalizado. Para Bourdieu, "o capital cultural é um ter que se tornou ser, uma propriedade que se fez corpo e tornou-se parte integrante da 'pessoa', um habitus" (BOURDIEU, 1998b, p. 74). Em sentido mais específico, o capital cultural em seu estado incorporado "[...] pressupõe um trabalho de inculcação e de assimilação, custa tempo que deve ser investido pessoalmente pelo investidor [...]" (ibidem). A biblioteca do bisavô de Flávio de Lacerda indica que ele era portador de capital cultural no estado objetivado, o qual é constituído por uma determinada quantidade de propriedades. Nesse aspecto, esse tipo de capital cultural é passível de ser herdado, pois é conformado por "suportes materiais, tais como escritos, pinturas, monumentos [pianos, livros] etc. [...]" (idem, p. 77). Para o sociólogo francês, "[...] é transmissível tão bem (senão melhor, porque num grau de eufemização superior) quanto o capital econômico" (ibidem). Além disso, Frederico Virmond era portador de diplomas (capital cultural institucionalizado). Além do mais, sua diplomação pela Universidade de Berlim potencializava seu capital cultural, pois tal instituição tinha grande reconhecimento (capital simbólico) em diferentes lugares do Ocidente, pois se tornou a expressão do modelo universitário prussiano/alemão.

A ambiência de educação de Flávio de Lacerda estava conformada pela convivência com os símbolos do capital cultural. Segundo Lacerda Neto, "em casa de sua genitora o ambiente seria bastante salutar, particularmente em termos culturais, a partir do bisavô prussiano Virmond, que aos quatro pares de filhos transmitiu em casa mesmo seus conhecimentos idiomáticos, científicos e de cultura geral" (LACERDA NETO, 1988, p. 8). Tais observações indicam que a infância de Flávio de Lacerda estava atrelada ao acesso aos bens culturais, pois seus familiares detinham capital cultural nos três estados (interiorizado, objetivado e institucionalizado). Essa condição tem um papel condicionante no processo de formação intelectual de Flávio de Lacerda, pois é a estrutura estruturada que se transforma em estrutura estruturante (habitus escolar). Segundo Renato Ortiz, "a expressão 'estrutura estruturada predisposta a funcionar como estruturante' significa que a noção de habitus não se aplica apenas à interiorização das normas e dos valores, mas inclui os sistemas de classificação que preexistem às representações sociais" (ORTIZ, 2003, p. 159).

Segundo Bourdieu, "as estruturas constitutivas [...] produzem habitus, sistemas de disposições duráveis, estruturas estruturadas predispostas a funcionar como estruturas estruturantes, isto é, como princípio gerador e estruturador das práticas e das representações que podem ser objetivamente 'reguladas' e 'regulares' sem ser o produto da obediência a regras, objetivamente adaptadas a seu fim sem supor a intenção consciente dos fins e do domínio expresso das operações necessárias para atingi-los e coletivamente orquestradas, sem ser o produto da ação organizadora de um regente (BOURDIEU, 2003a, p. 53-54).

Essa disposição ou esse habitus interiorizado por Flávio de Lacerda fazia parte do sistema de classificação social partilhado por seus familiares. De acordo com Patrice Bonnewitz, o habitus é produto da posição e da trajetória social dos indivíduos, pois "entre todas as ações pedagógicas que sofremos, as mais decisivas são as mais precoces, as que sofremos durante a infância, e que tiveram como resultado inculcar-nos um habitus primário. [...] O grupo familiar desempenha um papel preponderante nessa socialização primária. [...] Receber uma educação [...] é adquirir disposições para reproduzir espontaneamente, em e por seus pensamentos, suas palavras, suas ações, as relações sociais existentes no momento de aprendizagem. [...]. Interiorizamos as propriedades ligadas à posição de nossos pais no espaço social. Sujeitos situados em condições sociais diferentes vão adquirir disposições diferentes" (BONNEWITZ, 2003, p. 78-79).

De acordo com Ortiz, "o habitus adquirido na família está no princípio da estruturação das experiências escolares, o habitus transformado pela escola, ele mesmo diversificado, estando por sua vez no princípio da estruturação de todas as experiências ulteriores" (ORTIZ, 2003, p. 161). Nesses termos, o acesso de Flávio de Lacerda à educação escolar representou a reafirmação das disposições culturais herdadas do espaço de socialização primária.

A primeira experiência escolar de Flávio de Lacerda aconteceu no Colégio São José, na cidade da Lapa. 
Esse estabelecimento de ensino era coordenado pelas Irmãs de São José de Môutiers. A vinda de religiosas para o Paraná teve início na década de 1890, quando "Dom José de Camargo [...] recorreu a ordens e congregações estrangeiras [...] para que o apoiassem [...] instituindo escolas [...]" (PIZANI, 2005, p. 107). Em 1896, as Irmãs de São José de Môutiers chegaram a Curitiba. Segundo Maria Angélica Pizani (idem, p. 121), "em primeiro de fevereiro de 1906 também iniciaram seus trabalhos quatro religiosas no Colégio São José da cidade da Lapa". Segundo a mesma autora, a vinda dessa congregação religiosa "[...] para o Brasil não se constitui um fato isolado, apenas atendendo à solicitação de um bispo, mas sim fez parte de um contexto de planejamento da Igreja Católica" (idem, p. 27).

A primeira experiência escolar de Flávio de Lacerda está marcada pela cultura católica. De acordo com Névio de Campos, "o projeto formativo [católico] preconizava a formação integral [...], isto é, a formação religiosa, moral, cívica/patriótica e intelectual" (CAMPOS, 2010, p. 175). Seu ingresso no Colégio das Irmãs de São José evidencia a estreita relação ente sua família e a tradição católica. Outra observação que indica tal assertiva é a afirmação de Lacerda Neto: "nas novenas de Sant'Ana, celebrada nas residências dos fiéis, expandia-se em peraltices [...]" (LACERDA NETO, 1988, p. 9). A participação de seus familiares nas celebrações católicas e a sua matrícula no Colégio São José evidencia a presença da cosmovisão religiosa na formação de Flávio de Lacerda. Segundo Ivan Manuel, "[...] a educação católica [...] propunha a formação [...] para a Cidade de Deus. É bem verdade que a Igreja [...] jamais instigou seus fiéis contra o Estado. Ao contrário, sempre ensinou que o bom católico deve ser ordeiro, obediente, respeitador da ordem constituída" (MANUEL, 1996, p. 18-19). Portanto, ao lado da ascendência ligada à aristocracia paranaense, seus familiares tinham profunda vinculação com a tradição católica.

Porém, de acordo com Lacerda Neto, entre 1912 e 1915 passou a estudar no Colégio Julio Theodorico, na capital do Paraná. O referido colégio pertencia a Julio Theodorico Guimarães ${ }^{22}$, que exercia a função de diretor. Existiam diversas escolas particulares em

\footnotetext{
22 Julio Theodorico Guimarães (contador) pertencia ao círculo intelectual do grupo envolvido com projetos formativos na capital paranaense. Além de ser proprietário da referida escola que levava seu próprio nome, tinha projetos educativos com Flavio Luz, diretor do Gymnasio Curytibano. Juntamente com Flavio Luz, participou do processo de organização dos cursos da Universidade do Paraná, em 1912. Depois de criada assumiu a função de professor no Curso de Comércio. Os três primeiros
}

Curitiba daquele contexto, com presença marcante de instituições católicas e étnicas. O Colégio Julio Theodorico funcionava nos sistemas internato, semiinternato e externato. Ofertava a educação primária, intermediária e secundária. Conforme Relatório do Governo do Paraná, em 1916, por exemplo, no Colégio Julio Theodorico, 228 alunos estavam matriculados, o que indica um número significativo para aquele contexto, pois apenas alguns colégios possuíam um contingente maior de alunos. A partir do número de alunos, assim como da memória criada a respeito do proprietário/diretor, é possível afirmar que, no cenário público de Curitiba, o Colégio Julio Theodorico era reconhecido como uma instituição de ensino de prestígio. É interessante observar que a família de Flávio de Lacerda preferiu fazer a matrícula dele em colégio que não estava vinculado a ordem religiosa ${ }^{23}$.

Em 1915, Flávio de Lacerda foi matriculado no Colégio Militar de Barbacena ${ }^{24}$, concluindo sua formação em dezembro de 1922. Assim, Lacerda Neto narra essa nova experiência: "os derradeiros meses de 1915 corresponderam ao período final por Flávio Lacerda vivido em Curitiba durante sua infância e meninice, para transcorrer a adolescência e início da juventude fora dela, mesmo de seu estado natal, pelo interregno de doze anos"25 (LACERDA NETO, 1988, p. 11). Segundo Lacerda Neto, "partiu em princípios de 1916, conduzido pelo pai [...]" (ibidem).

De acordo com Fabiana Maria Leal, "o primeiro Colégio Militar no Brasil foi criado em 1888 na cidade do Rio de Janeiro. Este tinha como finalidade garantir

mentores da organização do curso superior no Paraná, em 1912, foram Nilo Cairo da Silva, Flavio Luz e Julio Theodorico. Atesta nossa afirmação, o relatório apresentado por Nilo Cairo da Silva, "[...] ahi $[$ sic $]$ compareceu, de facto, o Dr. Flavio Luz, levando em sua companhia o illustre [sic] professor Sr. Julio Theodorico Guimarães, hoje lente do Curso de Commercio desta Universidade [...]" (SILVA, 1913, p. 14). Além disso, observa Nilo Cairo da Silva, "da discussão travada, porém, em torno da ideia de um curso particular de odontologia e de commercio (o projeto havia crescido), que apresentava vários inconvenientes, nasceu a resolução da parte de nós três de fundarmos esses mesmos cursos com o caráter de uma associação civil" (idem, p. 15). Atesta, ainda, Cairo da Silva, "ainda que acompanhando o nosso pensamento, o Sr. Julio Theodorico Guimarães, por seus muitos afazeres, não pode mais comparecer às nossas reuniões" (ibidem).

23 Esse aspecto merece novas pesquisas, pois no momento não podemos discutir por falta de evidências empíricas.

24 Fundado em 1912 e fechado em 1925.

25 Em rigor, Flávio de Lacerda ficou 13 anos fora do Paraná, pois iniciou seus estudos nos primórdios de 1916 (Colégio de Barbacena) e concluiu em dezembro de 1928 (Escola Politécnica de São Paulo). 
a educação dos órfãos de militar [...]. O colégio tinha como grande diferencial a instrução e educação militar, induzindo os alunos a seguirem carreiras nas Forças Armadas" (LEAL, 2009, p. 1). O Colégio acumulou, já nas primeiras décadas de sua história, reconhecimento social. Tal representação garantiu a criação de outros estabelecimentos de ensino, como por exemplo, em Porto Alegre e Barbacena em $1912 \mathrm{e}$ Fortaleza, em 1919. Na avaliação de Fabiana Leal, o Exército defendia "a idéia de espalhar uma rede de colégios militares pelo Brasil para colecionar homens valorosos, tanto para o Exército quanto para as carreiras civis" (idem, p. 8).

Outro elemento marcante na trajetória formativa de Flávio de Lacerda é sua adesão ao positivismo. Segundo Lacerda Neto, "recebeu influências do positivismo através dos professores Major Augusto de Araújo Dória e Major Leyraud, ambos aderentes à doutrina de Augusto Comte, influência intensificada pelos regentes das disciplinas científicas que em aula confirmavam a classificação das ciências estabelecidas pelo filósofo de Montpellier. Manifestou simpatias para com a Religião da Humanidade, freqüentando, embora inassiduamente, as exposições do Dr. João Gambetta Perissé [...]" (LACERDA NETO, 1988, p. 12).

Entretanto, em meados da década de 1930, Flávio de Lacerda integrava o Círculo de Estudos Bandeirantes, órgão da intelectualidade católica paranaense. De acordo com Lacerda Neto, "tais convicções [positivistas] desapareceram ulteriormente, atingindo manifesta hostilidade quando reitor, ao equiparar positivismo a comunismo destruidor [...]" (ibidem).

Em 1923, ingressou na Escola Politécnica de São Paulo, concluindo o curso de Engenharia Civil em dezembro de 1928. Essa referida escola foi criada em 1900. De acordo com Luiz A. Cunha, "o ensino de engenharia surgiu, no Brasil, como em outros países, da diferenciação do ensino militar" (CUNHA, 1986, p. 104). A Escola Central (Rio de Janeiro) foi criada em 1858, na qual eram ofertados os cursos de Engenharia Civil e Engenharia Geográfica. Em 1874, essa escola passou a chamar-se Escola Politécnica, destinada ao ensino de engenharia civil e desvinculada diretamente do ensino militar. Nessa instituição, o currículo estava estruturado em curso geral (dois anos) e curso de bacharelado/profissional (três anos). Na Escola Politécnica de São Paulo, no período de estudo de Flávio de Lacerda, predominava uma estrutura semelhante, pois nos dois primeiros anos estavam sistematizados os estudos gerais (geometria analítica, cálculo infinitesimal, física experimental, mecânica racional, astronomia e geodesia, química, minerologia, geologia etc.) e, nos três seguintes, as disciplinas de especialização profissional (economia política, estradas e tráfego, navegação, rios, canais e portos, motores térmicos e de ar comprimido, pontes e viadutos, resistência e estabilidade etc. $)^{26}$. De acordo com Miceli, a década de 1920 "se caracterizou pela presença do engenheiro no domínio dos estudos sociais" (MICELI, 2001b, p. 117). Em termos mais precisos, "a era dos 20 assinalou a presença dos engenheiros não chamados ainda a resolver problemas estritamente tecnológicos, como agora, mas atraídos pelo desejo de estudar e explicar os problemas sociais em todo o seu conjunto" (ibidem).

A trajetória formativa de Flávio de Lacerda representa a materialização do estado cultural institucionalizado. Segundo Bourdieu, "com o diploma, essa certidão de competência cultural que confere ao seu portador um valor convencional, constante $\mathrm{e}$ juridicamente garantido no que diz respeito à cultura, a alquimia social produz uma forma de capital cultural que tem uma autonomia relativa em relação ao seu portador e, até mesmo em relação ao capital cultural que ele possui, efetivamente, em um dado momento histórico" (BOURDIEU, 1998b, p. 78).

$\mathrm{O}$ acesso a esse estado do capital cultural permitiu a Flávio de Lacerda, entre outras posições, ingressar no quadro de professores da Faculdade de Engenharia do Paraná em 1930. Durante três anos exerceu atividades docentes na condição de professor contratado temporariamente. Em 1933, prestou concurso à cadeira de Resistência dos Materiais e Grafoestática, no qual obteve aprovação. No processo de seleção, sua atuação resultou na indicação de seu estudo sobre Flambagem ${ }^{27}$ para uso no ensino dos cursos da Escola Nacional de Belas Artes (considerado único trabalho sobre o tema), assim como tal investigação foi reconhecida como tese de livre docência ${ }^{28}$.

Segundo Bourdieu, "ao conferir ao capital cultural possuído por determinado agente um reconhecimento institucional, o certificado escolar permite, além disso,

\footnotetext{
26 Flávio de Lacerda concluiu o Curso de Engenharia Civil em seis anos, pois de acordo com Lacerda Neto (1988) foi reprovado em uma série.

27 Conforme Lacerda Neto, Flávio publicou o livro Estudo do fenômeno de flambagem, editado "em 1931 por João Haupt e Cia, prefaciado pelo colega Adriano Gustavo Goulin e homenageando os ex-professores da Politécnica Oscar Machado de Almeida e Mario Wathely" (idem, p. 26-27).

28 Aos 30 anos assumiu uma cátedra na Faculdade de Engenharia do Paraná, assim como recebeu os títulos de Doutor e de Livre-Docente.
} 
a comparação entre os diplomados e, até mesmo, sua 'permuta' [...]" (ibidem). Além do mais, assevera o autor, "permite também estabelecer taxas de convertibilidade entre o capital cultural e o capital econômico, garantindo o valor em dinheiro de determinado capital cultural" (idem, p. 78). O ingresso de Flávio de Lacerda ao quadro docente da Faculdade de Engenharia garantiu o reconhecimento de seu capital herdado, seja cultural e/ou social. Em terminologia bourdieusiana, é possível afirmar que tais capitais converteram-se em capital simbólico, representando o prestígio ou boa reputação que Flávio de Lacerda passou a acumular no campo intelectual e na sociedade curitibana em geral.

O capital cultural tem uma importância significativa nas sociedades modernas, pois cumpre uma função de organização social das instituições. A Revolução Francesa expressa o símbolo da nova organização da história europeia, particularmente em razão "[...] de pôr fim à sociedade aristocrática. Não à 'aristocracia', no sentido da hierarquia de status social distinguido por títulos ou outras marcas visíveis de exclusividade, e que muitas vezes se moldava no protótipo dessas hierarquias, a nobreza 'de sangue"" (HOBSBAWM, 2004 , p. 255). Essa nova configuração social destituiu a herança automática por via consangüínea. Ou seja, a sucessão deixou de ser apenas uma reprodução familiar. Entretanto, “o fim da sociedade aristocrática não significou o fim da influência aristocrática" (idem, p. 256). Ao lado da herança familiar passou-se a considerar a carreira aberta ao talento, na terminologia de Hobsbawm, ou o capital cultural, na expressão de Bourdieu como um dos elementos constituintes das novas condições do homem moderno. Porém, na história europeia dos séculos XVIII e XIX, assevera Hobsbawm, "nem os negócios nem a educação eram grandes estradas abertas para todos". Em contrapartida, "em certo sentido, a educação representava a competição individualista, a 'carreira aberta ao talento' e o triunfo do mérito sobre o nascimento e os parentescos, através do instrumento do exame competitivo" (HOBSBAWM, 2004, p. 266).

Esse movimento cultural que, tem na organização escolar uma de suas expressões, tenderá a estabelecer uma determinada autonomia do campo intelectual. É em razão da importância que o capital cultural assumirá no mundo social moderno que os homens das letras passarão a ganhar espaço em outros campos sociais. Ou, na denominação de Bourdieu, é com o processo de autonomia do campo intelectual que os letrados passam a promover intervenções no campo político. Segundo Bourdieu, "é só no final do século [XIX], no momento em que o campo literário, o campo artístico e o campo científico acedem à autonomia, que os agentes mais autónomos destes campos autónomos podem intervir no campo político enquanto intelectuais" (BOURDIEU, 1996, p. 382). O campo de produção cultural passa a constituir-se no contexto da história das revoluções francesas e industrial, no qual ganha valor um mercado de trocas culturais e simbólicas. É fundamental chamar a atenção para o cuidado em compreender o campo cultural, pois a sua autonomia "varia consideravelmente não só de acordo com as épocas de uma mesma sociedade, mas também de acordo com as sociedades" (BOURDIEU, 2004, p. 175). Em rigor, conforme Giséle Sapiro, para Bourdieu o processo de autonomia do campo de produção cultural está associado "a emergência de um corpo de produtores especializados; a existência de instâncias de consagração específicas; a existência de um mercado"29 (SAPIRO, 2004, p. 93).

Os estudos de Miceli analisam as ações dos intelectuais no Brasil, enfatizando os elementos que contribuíram para a emergência da figura do intelectual e do próprio campo de produção cultural. Esse sociólogo brasileiro destaca que, entre as décadas de 1920 e 1940, houve mudanças nos planos econômico, social, político e cultural, permitindo uma relativa autonomia do campo de produção cultural. Em rigor, Miceli assinala que as "organizações partidárias e as instituições culturais", "o mercado do livro" e o "serviço público" foram elementos condicionantes para o processo de constituição do campo cultural brasileiro $^{30}$ (MICELI, 2001b, p. 76). É importante assinalar que os estudos de Miceli cobrem as ações dos intelectuais dos grandes centros brasileiros, particularmente a região Sudeste. Entre suas

29 O debate em torno dos intelectuais e do campo de produção cultural no contexto europeu é intenso e merece abordagem de muitos autores, entre os quais destacamos Charle (1989); Sirinelli (1990); Bourdieu (1996; 2002; 2003b; 2004; 2008); Bobbio (1997); Bastos e Rêgo (1999); Rodrigues (2002; 2003; 2005); Zuin (2003); Sapiro (2004; 2005; 2009).

30 Outros estudos discutem o problema do campo cultural brasileiro, como por exemplo, Pécaut (1990), Schwartzman, Bomeny e Costa (2000) e Sevcenko (2003). Talvez, mereça uma nota a diferença entre as abordagens de Pécaut e Miceli. Pécaut analisa a relação entre intelectuais e Estado, enfatizando a acepção de sentimento de missão que orientava as intervenções dos homens das letras no campo político. Já Miceli indica a profunda relação social entre intelectuais e classe política no Brasil, embora chame a atenção ao papel do capital cultural que detinham os intelectuais. Ao leitor sugerimos acompanhar as respostas dadas por Miceli a Pécaut no texto intitulado "Intelectuais brasileiros", publicado na obra Intelectuais à brasileira(MICELI, 2001c). O presente artigo, além de contrapor-se a Pécaut, faz uma síntese de algumas das principais tendências analíticas dos intelectuais brasileiros. 
observações destacamos o papel exercido pelas faculdades tradicionais (Direito, Medicina e Engenharia) no contexto brasileiro, embora ele saliente que as faculdades de humanidades ${ }^{31}$, criadas na década de 1930, tiveram papel de maior relevância no processo de autonomização do campo cultural. É nesse contexto de significativo prestígio dessas instituições tradicionais de ensino superior que ocorreu a formação acadêmica de Flávio de Lacerda. Na avaliação de Miceli, foi intensa "a presença do engenheiro nas áreas de estudos sociais, do pensamento político, da produção de obras pedagógicas, no exercício de cargos administrativos em instituições escolares ou entidades e associações corporativas" (idem, p. 117-118). Para Miceli, essa intervenção social do engenheiro deviase a "formação humanista e letrada que subsistia nas escolas politécnicas desde os tempos do Império e pelas transformações por que passava o mercado de postos destinados aos detentores de diplomas superiores" (idem, p. 118), assim como pela ausência de um campo intelectual das ciências humanas capaz de sistematizar uma visão do e sobre o mundo social.

A condição de portadores de diplomas permitia aos intelectuais associarem-se às prerrogativas do Estado, ocupando funções de intervenção no mundo social. $\mathrm{Na}$ interpretação de Monica Velloso, "é a partir da década de 1930 que eles [intelectuais] passam sistematicamente a direcionar sua atuação para o âmbito do Estado, tendendo a identificá-lo com a representação superior da idéia de nação" (VELLOSO, 2003 , p. 148). Ela avança na sua avaliação ao afirmar que "o intelectual é eleito o intérprete da vida social porque é capaz de transmitir as múltiplas manifestações sociais, trazendo-as para o seio do Estado, que irá discipliná-las e coordená-las" (idem, p. 155). Nos estudos de Miceli a ocupação das esferas do Estado constitui-se em um dos elementos da própria condição do intelectual brasileiro. Para ele, "os intelectuais recrutados pelo regime Vargas assumiram as diversas tarefas políticas e ideológicas determinadas pela

31 Leia-se Faculdade de Filosofia, Ciências e Letras (FFCL) da USP e Escola de Sociologia e Política de São Paulo.

32 A investigação de Miceli evidencia a constituição do campo acadêmico brasileiro entre as décadas de 1920 e 1940, enfatizando que no plano cultural houve "criação de novos cursos superiores, expansão da rede de instituições culturais, surto editorial etc." (MICELI, 2001b, p. 77). Essas mudanças no campo cultural brasileiro representaram alterações no mercado de trabalho intelectual, o que tenderá a constituir certa autonomia ao campo intelectual. O campo intelectual brasileiro pode ser discutido a partir de um conjunto de autores, entre os quais destacamos Miceli (idem), Pécaut (1990), Schwartzman, Bomeny e Costa (2000), Sevcenko (2003) e Velloso (2003). Já crescente intervenção do Estado nos mais diferentes domínios de atividade"32 (MICELI, 2001b, p. 197).

O campo de produção cultural configurou-se no final do século XIX na Europa. Já no Brasil, conforme Miceli, ocorreu entre as décadas de 1920 e 1940. No Paraná, desde a década de 1910 , com a criação da Universidade, um grupo de especialistas (médicos, engenheiros e bacharéis em Direito) assume as funções acadêmicas e passa a requerer o direito de intervir nos espaços sociais. As faculdades tradicionais representam a institucionalização de um grupo de especialistas que estão associados diretamente ou indiretamente com as camadas políticas paranaenses. $\mathrm{Na}$ década de 1930, uma parte desse grupo associase à tradição filosófica católica do Círculo de Estudos Bandeirantes e da Faculdade de Filosofia, Ciências e Letras do Paraná (FFCL), objetivando sistematizar um pensamento social e intervir na direção política ${ }^{33}$. Em rigor, criada em 1938, a FFCL passou a congregar um conjunto de professores que ao longo das décadas vão estabelecer os cursos de ciências humanas e ciências sociais ${ }^{34}$.

Em síntese, a formação cultural de Flávio de Lacerda, que culminou com a titulação de engenheiro pela Escola Politécnica de São Paulo, deve ser compreendida nesse movimento de autonomização do campo de produção cultural no Brasil e no Paraná, cuja presença dos especialistas no mundo da política ganha dimensões mais marcantes a partir da década de 1930. Nesse aspecto, a trajetória escolar de Flávio de Lacerda evidencia a conversão do capital cultural herdado (estados incorporados e objetivado) em capital cultural adquirido (estado institucionalizado), pois o diploma em engenharia foi um dos trunfos para ocupar

o debate do campo intelectual paranaense pode ser acompanhado pelo conjunto de pesquisas, entre elas Pereira (1997), Szvarça (1998), Bega (2001; 2003) e Cordova (2003; 2007; 2009). O processo de constituição das Ciências Sociais no Brasil foi tratado por muitos autores, destacando-se Fernandes (1977), Miceli (2001a), Barreira (2003) e Ortiz (2003). Já no contexto paranaense merece destaque os trabalhos de Tomazi et alii (2001), Tomazi (2006) e Melo (2005).

33 Nesse espaço não é possível discutir o processo de constituição do campo de produção cultural no Paraná, pois além de ser um problema complexo, extrapola aos objetivos do presente artigo. Entretanto, ao leitor indicamos algumas obras da área de Ciências Humanas que poderão indicar direções a esse problema. Sugerimos consultar Pereira (1997), Szvarça (1998), Bega (2001; 2003), Tomazi (2001; 2006), Cordova (2003; 2007; 2009), Vieira (2007), Campos (2008; 2010), Szwako e Oliveira (2009) e Oliveira (2009).

34 Sugerimos consultar Westphalen (1988), Tomaziet alii (2001), Tomazi (2006) e Campos (2008). 
espaços no mundo acadêmico da Faculdade de Engenharia e da Universidade do Paraná, assim como em outros campos do mundo social, particularmente no Ministério da Educação.

\section{CONCLUSÕES}

Nesta parte conclusiva, gostaríamos de abordar três aspectos: $(i)$ a articulação deste texto com a produção acadêmica sobre a vida intelectual paranaense; (ii) o lugar de análise desta narrativa; (iii) o sentido e o significado deste artigo.

A produção acadêmica tem se debruçado sobre o problema dos intelectuais, da cultura e da política no Paraná. Em rigor, apenas com uma pesquisa que tenha por objeto promover um balanço de tais investigações poderemos ter uma percepção mais consistente a respeito do estado da arte do campo de produção cultural paranaense. Entretanto, é possível sustentar que há um significativo contingente de pesquisas cujo recorte analítico perpassa pelos conceitos "intelectuais" e "Paraná", pois com o avanço dos programas de pós-graduação houve um aumento representativo de pesquisas. Nesse sentido, há trabalhos no campo da Sociologia, História, Educação e Literatura que retratam a relação entre intelectuais, cultura e política no Estado do Paraná, portanto, que abordam o campo de produção cultural. Não obstante o aumento dessa produção, as observações de Léon Szwako e Márcio de Oliveira de que "a história social e intelectual do Paraná ainda está por ser escrita" (SZWAKO \& OLIVEIRA, 2009, p. 7) têm um grau bastante significativo de veracidade. Entretanto, cremos que é possível afirmar que a história social e intelectual de qualquer lugar está sempre por ser escrita e reescrita. Na avaliação desses pesquisadores, “[...] para contribuir com o esforço de 'contar' essa história, seria necessário um esforço amplo e crítico que girasse em torno dos termos 'história intelectual', 'sociologia do campo intelectual', assim como 'Paraná' [...]" (ibidem). Em nosso entendimento, o primeiro esforço da comunidade acadêmica deveria consistir na elaboração de um projeto coletivo e interinstitucional com o objetivo de mapear as produções já existentes. Ou seja, uma iniciativa bastante significativa que os espaços acadêmicos podem tomar é elaborar um balanço profundo da produção existente, pois dada a inexorável especialização das abordagens, não é raro o desconhecimento de investigações existentes em suas próprias instituições e mesmo em seus próprios programas de pós-graduação.

Sem dúvida a narrativa do nosso texto ganhou materialidade sem considerar a produção completa existente. Seria por demasiado presunçoso, de nossa parte, pretender afirmar que não ignoramos muitas das pesquisas que tratam do problema dos intelectuais, da cultura e política no Paraná. Porém, a primeira observação dessa parte conclusiva tem a pretensão de debater a hipótese de que a história intelectual e social do Paraná precisa ser escrita ou reescrita, chamando a atenção para o fato da inexistência de pesquisas e obras que tenham em seus horizontes analíticos a própria produção acadêmica sobre tal problema.

O segundo aspecto de nossas considerações finais diz respeito ao sentido deste artigo. A pretensão deste texto foi discutir alguns aspectos da vida de Flávio Suplicy de Lacerda, enfatizando o espírito de família e capital cultural como possibilidades de compreensão da trajetória de um intelectual. Dessa forma, privilegiamos a reconstituição histórica da linhagem familiar desse intelectual paranaense, assim como da sua formação cultural. Entretanto, tal recorte não desconsiderou a importância de discutir-se a formação cultural de modo articulado ao processo de autonomização do campo de produção cultural no Brasil e no Paraná.

Na obra "Intelectuais paranaenses e as concepções de universidade - 1892-1950" (CAMPOS, 2008), problematizamos a ação de diferentes personagens e grupos que estiveram envolvidos com o ensino superior no Estado do Paraná. Nessa história também esteve envolvido Flávio de Lacerda, principalmente ao longo do processo de federalização da Universidade do Paraná (1950). De acordo com Campos, “[...] em dezembro de 1949, [...] Flávio S. de Lacerda lançou oficialmente o movimento em defesa da federalização da UP [...]" (idem, p. 222). Mais adiante, reitera que "o movimento pela federalização da UP foi lançado e coordenado por Flávio Suplicy de Lacerda [...]. Suplicy de Lacerda, professor e reitor, naquele momento organizava o projeto de expansão da cultura universitária pelo interior do estado" (idem, p. 227). Em nossa avaliação, esta obra discute o papel intelectual de Flávio de Lacerda, porém não explora as razões que contribuíram para sua posição de liderança no projeto da federalização da Universidade do Paraná. Nesse sentido, o presente artigo representou uma ampliação analítica, pois buscou problematizar o espírito de família e o capital cultural como estratégias utilizadas por Flávio de Lacerda para ingressar nos principais espaços do cenário paranaense e assumir papeis de coordenação e liderança política na Universidade do Paraná e nas esferas do Estado. É importante destacar que este texto não tratou diretamente da atuação de Suplicy de Lacerda na reitoria da UFPR e no Ministério da Educação, pois o recorte previa problematizar a origem familiar e formação cultural herdada e adquirida por essa 
personagem até o período de seu ingresso como professor na Faculdade de Engenharia do Paraná.

Essa abordagem da trajetória de Flávio de Lacerda está associada ao lugar de destaque dessa personagem na história do ensino superior paranaense, mas, sobretudo, está vinculada às hipóteses advindas das obras de Pierre Bourdieu, particularmente dos conceitos de capital social, capital cultural, trajetória e estratégia. As categorias de espírito de família e capital cultural mostraram-se fecundas à nossa análise, pois permitiram discutir que as estruturas estruturadas converteram-se em estruturas estruturantes na trajetória de Flávio de Lacerda, isto é, contribuíram para compreender que esse intelectual ao interiorizar as estruturas estruturadas, incorporou o senso prático como sentido de jogo, como estratégia para ingressar no campo intelectual, assim como para ampliar seus espaços de ação nesse próprio campo e no campo político.

Por fim, outro aspecto importante a mencionar é que esta análise insere-se na História dos Intelectuais e/ou Sociologia dos Intelectuais, pois buscou discutir as redes sociais e a formação cultural de uma personagem que esteve atrelada aos grupos dirigentes e dominantes do Paraná. Ao inserir tal investigação nessa área opera-se em uma fronteira difícil de ser estabelecida entre as interpretações estruturais e conjunturais. Em outros termos, entre uma explicação externalista (mundo social) e uma explicação internalista (mundo individual). Existem várias formas de escrever uma história dos intelectuais, entre elas a história biográfica. O problema da biografia é destacado por Bourdieu ao chamar a atenção para a "ilusão biográfica", ou seja, a pretensa ideia de observar nas trajetórias individuais uma unidade, uma identidade coerente. A biografia, na sua origem, era considerada diferente da história. Porém, na segunda metade do século $X X$, esse gênero ganhou espaço na própria escrita histórica, assumindo o caráter de biografia intelectual, diferentemente da biografia pessoal.

Analisar a origem familiar e o percurso formativo e educativo de Flávio de Lacerda pode parecer uma abordagem que privilegia um olhar para o caminho, para um cursos. Porém, tal impressão não poderá prevalecer, pois pactuamos com a crítica de Bourdieu à ilusão biográfica, a qual consiste em desconstruir a hipótese de que a vida é em si uma história - um caminho que percorremos e que deve ser percorrido, um trajeto, uma corrida, um cursos, uma passagem, uma viagem. A pretensão dessa análise distancia-se da acepção tradicional de biografia, na qual a categoria trajetória é apropriada de modo indiferente às particularidades circunstanciais e aos acidentes individuais no fluxo das realidades sociais.

Em síntese, neste texto objetivou-se estabelecer uma síntese entre o local-global, o singular-universal. Portanto, procurou fugir ao rótulo da história "acontecimental" - história linear, superficial e anedótica, bem como da história estrutural. Aqui buscou-se privilegiar uma abordagem próxima ao modelo representacional, no qual a trajetória de Flávio de Lacerda não ocorre em função do que há de singular na sua vida, mas particularmente porque sintetiza várias outras biografias. Nesta análise da trajetória dessa personagem buscamos compreender o social reconstruindo a estrutura da rede na qual esse intelectual estava inscrito e agia, tal qual preconiza a nova biografia histórica. Nessa abordagem, o individual não é visto em oposição ao social - o social é produto da ação de indivíduos em suas relações com outros indivíduos. Problematizou-se a trajetória dessa personagem para, por meio dela, percorrer em diversos espaços e tempos as relações nas quais ela se inscreveu.

Névio de Campos (nmestrado@ig.com.br) é Doutor em Educação, Linha História e Historiografia da Educação pela Universidade Federal do Paraná (UFPR) e Professor na Universidade Estadual de Ponta Grossa (UEPG).

\section{REFERÊNCIAS BIBLIOGRÁFICAS}

BARREIRA, C. (org.). 2003. A Sociologia no tempo: memória, imaginação e utopia. São Paulo: Cortez.

BASTOS, E. R. \& RÊGO, W. D. L. 1999. Intelectuais e política: a moralidade do compromisso. São Paulo: Olho d'Água.

BEGA, M. T. S. 2001. Sonho e invenção do Paraná: geração simbolista e a construção de identidade regional. São Paulo. Tese (Doutorado em Sociologia). Universidade de São Paulo.
2003. No centro e na periferia: a obra histórica de Rocha Pombo. In: LOPES, M. A. (org.). Grandes nomes da história intelectual. São Paulo: Contexto.

BOBBIO, N. 1997. Intelectuais e poder: dúvidas e opções dos homens de cultura na sociedade contemporânea. São Paulo: UNESP.

BONNEWITZ, P. 2003. Primeiras lições sobre a sociologia de P. Bourdieu. $2^{\mathrm{a}}$ ed. Petrópolis: Vozes. 
BOURDIEU, P. 1996. As regras da arte: gênese e estrutura do campo literário. São Paulo: Companhia das Letras.

1998a. O capital social - notas provisórias. In: NOGUEIRA, M. A. \& CATANI, A. (orgs.). Escritos da educação. $6^{\mathrm{a}}$ ed. Petrópolis: Vozes.

1998b. Os três estados do capital cultural. In: NOGUEIRA, M. A. \& CATANI, A. (orgs.). Escritos da educação. $6^{\mathrm{a}}$ ed. Petrópolis: Vozes.

. 2002. O poder simbólico. Rio de Janeiro: Bertrand Brasil.

. 2003a. Esboço de uma teoria da prática. In: ORTIZ, R. (org.). A sociologia de Pierre Bourdieu. São Paulo: Olho d'água.

2003b. O campo científico. In: ORTIZ, R. (org.). A sociologia de Pierre Bourdieu. São Paulo: Olho d'Água.

. 2004. Campo intelectual: um mundo à parte. In: _ Coisas ditas. São Paulo: Brasiliense.

.2008. Razões práticas: sobre a teoria da ação. $9^{\mathrm{a}}$ ed. Campinas: Papirus.

2009. O senso prático. Petrópolis: Vozes.

CAMPOS, N. 2008. Intelectuais paranaenses e as concepções de universidade (1892-1950). Curitiba: UFPR.

2010. Intelectuais e igreja católica no Paraná (1926-1938). Ponta Grossa: UEPG.

CHARLE, C. 1989. La naissances de l'intellectuel (1889-1900). Paris: Minuit.

CORDOVA, M. J. W. 2003. A produção da memória e o patrimônio tombado na Lapa/PR: perspectivas para o currículo escolar. Ponta Grossa. Dissertação (Mestrado em Educação). Universidade Estadual de Ponta Grossa.

2007. O paranismo e o processo de produção historiográfica paranaense: o episódio do Cerco da Lapa. Revista de História Regional, Ponta Grossa, v. 12, n. 2, p. 151-190. Disponível em: http:// www.revistas2.uepg.br/index.php/rhr/article/ viewFile/2251/1736. Acesso em: 24.jul.2013.

2009. Tinguís, pioneiros e adventícios na mancha loira do sul do Brasil: o discurso regional de formação social e histórica paranaense. Curitiba. Tese (Doutorado em Sociologia). Universidade Federal do Paraná.

CUNHA, L. A. 1986. A universidade temporã: da colônia à era de Vargas. $2^{\mathrm{a}}$ ed. Rio de Janeiro: Francisco Alves.
FERNANDES, F. 1977. A Sociologia no Brasil. Petrópolis: Vozes.

FERREIRA，J. C. V. 1996. O Paraná e seus municípios. Maringá: Memória Brasileira.

FILHO, I. F. M. 2004. Ascendentes e descendentes de Joseph Sprenger e ascendentes e descendentes de Joaquim Ribeiro de Macedo Braga. Disponível em: http://pagfam.geneall.net/3935/familias. php?id=4055. Acesso em: 24.jul.2013.

HOBSBAWM, E. 2004. A era das revoluções na Europa (1789-1848). 18 ed. São Paulo: Paz e Terra.

KNEBEL, R. L. s. d. Visconde de Nácar. In: LEANDRO, J. A. (org.). Dicionário Histórico e Geográfico dos Campos Gerais. Ponta Grossa: UEPG. Disponível em: http://www.uepg.br/dicion/ verbetes/n-z/visconde.htm. Acesso em: 24.jul.2013.

LACERDA NETO, A. V. 1988. O magnífico reitor: biografia de Flávio Suplicy de Lacerda, ensaio de histórico da UFRP de 1949 a 1971. Curitiba: Instituto Histórico, Geográfico e Etnográfico paranaense.

LEAL, F. M. 2009. "Por trás dos portões": a disciplina no Colégio Militar de Curitiba (1959-1964). Curitiba. Monografia (Graduação em História). Universidade Tuiuti do Paraná.

MELO, E. G. 2005. As práticas profissionais do sociólogo como representações sociais dos alunos de ciências sociais da UFPR. Curitiba. Dissertação (Mestrado em Sociologia). Universidade Federal do Paraná.

MICELI, S. 2001a. História das Ciências Sociais no Brasil. São Paulo: Sumaré.

2001b. Intelectuais à brasileira. São Paulo: Companhia das Letras.

2001c. Intelectuais brasileiros. In:

Intelectuais à brasileira. São Paulo: Companhia das Letras.

OLIVEIRA, M. 2003. História intelectual e teoria política: confluências. In: LOPES, M. A. (org.). Grandes nomes da história intelectual. São Paulo: Contexto.

2009. Origens do Brasil meridional. Estudos Históricos, Rio de Janeiro, v. 22, n. 43, p. 218237, jan.-jun. Disponível em: http:// bibliotecadigital.fgv.br/ojs/index.php/reh/article/ view/1553/1002. Acesso em: 24.jul.2013. 
OLIVEIRA, R. C. 2001. O silêncio dos vencedores. Genealogia, classe dominante e Estado no Paraná. Curitiba: Moinho do Verbo.

2007. Famílias, poder e riqueza: redes políticas no Paraná em 2007. Sociologias, Porto Alegre, ano 9, n. 18, p. 150-169, jun.-dez. Disponível em: http:/ /www.scielo.br/pdf/soc/n18/n18a08.pdf. Acesso em: 24.jul.2013.

ORTIZ, R. 1998. Cultura brasileira e identidade nacional. São Paulo: Brasiliense.

2003. Ciências sociais e trabalho intelectual. São Paulo: Olho d'água.

PÉCAUT, D. 1990. Os intelectuais e a politica no Brasil: entre o povo e a nação. São Paulo: Ática.

PEREIRA, L. F. L. 1997. Paranismo - o Paraná inventado: cultura e imaginário no Paraná da Primeira República. Curitiba: Aos Quatro Ventos.

PIZANI, M. A. P. N. 2005. O cuidar na atuação das irmãs de São José de Môutiers na Santa Casa de Misericórdia de Curitiba (1896-1937). Curitiba. Tese (Doutorado em História). Universidade Federal do Paraná.

RODRIGUES, H. 2002. Fragmentos da história intelectual: entre questionamentos e perspectivas. Campinas: Papirus.

2003. A história intelectual em questão. In: LOPES, M. A. (org.). Grandes nomes da história intelectual. São Paulo: Contexto.

2005. O intelectual no "campo" cultural francês: do "Caso Dreyfus" aos tempos atuais. Varia Historia, Belo Horizonte, v. 21, n. 34, jul. Disponível em: http://www.scielo.br/pdf/vh/ v21n34/a08.pdf. Acesso em: 24.jul.2013

SAPIRO, G. 2004. Elementos para uma história do processo de autonomização: o exemplo do campo literário francês. Tempo Social, São Paulo, v. 16, n. 1, p. 92-105, jun. Disponível em: http:// www.scielo.br/pdf/ts/v16n1/v16n1a05.pdf. Acesso em: 24.jul.2013.

2005. Autonomia estética, autonomização literária. In: ENCREVÉ, P. \& LAGRAVE, R-M. (org.). Trabalhar com Bourdieu. Rio de Janeiro: Bertrand Brasil.

(dir.). 2009. L'espace intellectuel en Europe: de la formation des États-nations à la mondialisation (XIX-XXI siècle). Paris: La Découverte.

SCHWARTZMAN, S.; BOMENY, H. M. B. \& COSTA, V. M. R. 2000. Tempos de Capanema. São Paulo: Paz e Terra.
SEVCENKO, N. 2003. Literatura como Missão: tensões sociais e criação cultural na Primeira República. São Paulo: Companhia das Letras.

SZVARÇA, D. 1998. O forjador: ruínas de um mito, Romário Martins. Curitiba: Aos Quatro Ventos.

SILVA, N. C. 1913. Relatório didactico e administrativo. In:_. Relatório Geral da Universidade do Paraná. Curitiba: Alfredo Hoffmann.

SIRINELLI, J-F. 1990. Intellectuels et passions française. Paris: Fayard.

SZWAKO, J. \& OLIVERIA, M. (orgs.). 2009. Ensaios de sociologia e história intelectual do Paraná. Curitiba: UFPR.

TOMAZI, N. D. 2006. Considerações preliminares sobre a institucionalização da sociologia no Paraná. In: OLIVEIRA, M. (org.). As ciências sociais no Paraná. Curitiba: Protexto.

TOMAZI, N. D.; COLOGNESE, S. A.; SANTOS, C. A. \& PASTOR, C. A. P. 2001. A institucionalização da sociologia no ensino superior paranaense. Revista Mediações, Londrina, v. 6, n. 2, p. 227-245. Disponível em: http://www.uel.br/ revistas/uel/index.php/mediacoes/article/view/ 9127/7700. Acesso em: 24.jul.2013.

VELLOSO, M. P. 2003. Os intelectuais e a política cultural do Estado Novo. In: FERREIRA, J. \& DELGADO, L. A. N. (orgs.). O Brasil republicano: o tempo do nacional-estatismo - do início da década de 1930 ao apogeu do Estado Novo. Rio de Janeiro: Civilização Brasiliense.

VIEIRA, C. E. (org.). 2007. Intelectuais, educação e modernidade no Paraná (1886-1964). Curitiba: UFPR.

WACHOWICZ, R. C. 1977. História do Paraná. Curitiba: Vicentina.

1983. Universidade do mate: história da UFPR. Curitiba: APUFPR.

WESTPHALEN, C. M. 1988. Faculdade de Filosofia. Ciências e Letras do Paraná - 50 anos. Curitiba: SBPH.

ZUIN, J. C. S. 2003. Sobre o neologismo intelectual. Estudos de Sociologia, Araraquara, v. 8, n. 15, p. 85-101. Disponível em: http://seer.fclar.unesp.br/ estudos/article/download/160/158. Acesso em: 24.jul.2013. 


\section{OUTRAS FONTES}

ABCGENEALOGIA. 2013. XIX-ALFONSO X “el

Sabio" y "el Astrólogo". Disponível em: http://
www.abcgenealogia.com/Castilla $01 . \mathrm{html} \#$ CastillaXIX. Acesso em: 24.jul.2013. 
FLÁVIO SUPLICY DE LACERDA: GENEALOGY OF A MEMBER OF THE ELITE OF PARANÁ. Névio de Campos.

The aim of this article is to discuss Flávio Suplicy de Lacerda's trajectory, giving special emphasis to his family genealogy (social capital) and the cultural capital inherited and acquired as assets and used as dean of Paraná University and as Secretary of State for Paraná as well as Minister for Education in the military government of Castelo Branco. The hypothesis that family spirit and cultural heritage were strategies used by Flávio de Lacerda to adopt leading roles in the cultural and political scenario in Paraná and in Brazil. The hypothesis was discussed in the light of concepts of trajectory, strategy, family spirit and inherited and acquired cultural capital based on biographical and autobiographical data. This information was seen as the production of a memory and/or representation which seeked to sanctify this character. The biographical descriptions were crossed with the social and cultural contexts allowing to bring into play the theoretical apparatus and the empirical object. This analysis permits us to state that structured structures convert themselves into structuring structures in the path of the intellectual Flávio de Lacerda. In internalizing the structured structures, he incorporated the practical sense as being sense of play, as a strategy to enter the intellectual field as well as widen the space for action in this same field. Summing up, when taking the data as an attempt to sanctify the trajectory of Flávio de Lacerda and convert it into products of the process in social and cultural contexts, this article contributes towards the understanding of the complex relationship between the individual and society, that is, it evidences that the social and cultural assets function as powerful strategies to adopt leading roles in the political and cultural fields.

KEYWORDS: Trajectory; strategy; family spirit; cultural capital; elite of Paraná. 